\title{
Cinematographic Landscapes of Blackness in Mexico: (Re)Framing Afro-Mexican Lives \& Futures
}

\author{
Talia Weltman-Cisneros • Southern Methodist University
}

\begin{abstract}
The legacy of historical invisibility and socio-cultural marginalization and rejection have marred contemporary Afro-Mexican lives, silencing their stories, customs, traditions, and cosmologies, while also denying them a sense of belonging and place within the visions of the present and futures of Mexican landscapes. Mexican films have often echoed this estranged relationship between blackness and Mexicanidad, portraying black characters as stereotyped figures who have most often been marked as exotic, primitive, and alien or anachronic in Mexico. However, these subaltern imaginaries of blackness and of Afro-Mexicanidad are challenged in the recent films La negrada (2018) and Artemio (2017). This article reflects on these films' critique of Afro-Mexican real-life and cinematic inequality and subalternity through the lens of Afrofuturism and Black Speculative Arts, which I suggest offer counter-futures of black lives and foreground black protagonists as individuals and communities who can now "see their own" and stand as stakeholders in Mexico's present and future.
\end{abstract}

$\mathrm{S}$ audi Arabia's selection of the film Black Panther to be the first movie screened after the country's 35-year cinema ban marked a significant shift and renewed engagement with Afrofuturism. While this literary and musical movement is by no means new in its interrogation of cultural spaces as a means of highlighting and challenging the absence of black identity in the portrayal of futuristic landscapes (Mark Dery pointed his interrogation to the sphere of science fiction when he coined the term in his seminal essay "Black to the Future" in 1993), myriad cultural critics, scholars, and media outlets are now pointing to the current global success of Black Panther as a blockbuster-size reflection of the renaissance of Afrofuturism and the exploration and visualization of black identity, culture, struggles and triumphs in diverse futuristic landscapes (Fitzpatrick, "It's Not Just Black Panther"). That is, in a nod to Black Panther, scholars, artists, and critics are calling attention to current manifestations of and renewed interest in Afrofuturism, in order to facilitate connections between new generations and popular culture that echo the longtime calls for black communities to "see our own superheroes and the power that they can have on all of us in society" (Combs).

This renewed interest in Afrofuturism that has been stimulated by recent films such as Black Panther is not just about superheroes in the classical sense, but more importantly, recharges this movement's objectives in envisioning concrete connections between black individuals seeing "their own" as powerful protagonists and leaders who are integral stakeholders and power-brokers. It is a movement and discourse seeping into expanded spaces of reflection and resistance. In describing the first Afrofuturism Festival in Memphis Tennessee, held in April 2018, the event organizer and award-winning science fiction writer Sheree Renée Thomas described this festival as "an opportunity for the community and creatives across the Mid-South and beyond to think beyond the balcony, to use the arts and our imagination to explore different Memphis futures, [since] in many ways, to be black in this country is to be alien, and to be living in a dystopian society, so it's not an unnatural response to reach for science fiction to help deal with that experience" (Beifuss). For Thomas, this festival again stresses Afrofuturism's emphasis on seeing black futures (in this case, as an integral power-broker and stakeholder in Memphis futures), in order to critically interrogate the alien-ness or absences that are often related to the experiences of black individuals and communities, and to explore diverse articulations of black protagonism through the arts. 
Thus, whether in Saudi Arabia or in Memphis, Tennessee, USA, we can clearly observe the resurgence of this visionary, transdisciplinary and transcultural movement that continues to critique the global status quo of inequality and respond to the challenges of the representations of heritage, present, and, more importantly, futures as related to black identity and black lives. That is, this renaissance of Afrofuturism, or what Reynaldo Anderson and Charles E. Jones refer to as Afrofuturism 2.0, is once again providing for a useful platform and analytical lens with which to interrogate the representations of blackness across the black diaspora.

With this renewed interest, vis à vis "Afrofuturism 2.0," it has been interesting to see how other artists, scholars and critics have continued to incorporate or appropriate the core projects of Afrofuturism, and are now extending them to a more diversified notion of black diaspora in other socio-cultural contexts, artistic spaces, and in a multiplicity of geo-political spheres, where the power of voice, agency, representation, and futures is being re-envisioned, re-imagined, re-framed, and re-appropriated by black communities and allies across the globe.

For example, Kodwo Eshun extends Dery's conceptualization of Afrofuturism and posits that the movement is "a program for recovering the histories of counter-futures created in a century hostile to Afro-diasporic projection" (301). Here, Eshun explicitly links histories with futures via the notion of recovery. That is, the recovery of black histories (an echo of Dery's insistence on "other stories to tell"), simultaneously serves as a "counter-future" or as an-other projection of black futures. Similarly, Lisa Yaszek goes further in her approach to Afrofuturism as "a larger aesthetic mode that encompasses a diverse range of artists working in different genres and media who are united by their shared interest in projecting black futures derived from Afro-diasporic experiences" ("Afrofuturism”). Thus, while both of these scholars align with Dery's challenge to and call for the (re)imagining, imaging, and projecting of black futures, this direct emphasis on historical recovery as counter-future (Eshun) and the foregrounding of experience (Yaszek), positions these extended threads as the main loci of enunciation through which black agency and black protagonism (superheroes) of the diverse Afro-diasporic sphere give voice to the myriad "other stories to tell" and futures to envision.

In addition, I would further suggest that Yaszek's articulation of Afrofuturism as a "larger aesthetic mode" is particularly useful as it allows us to move beyond the contexts of technoculture and science fiction, as originally focused upon by Dery, and instead foreground Afro-diasporic experience in its plethora of forms and expressions as the base for the imagination, enunciation, and representation of black futures, or counter-futures. In fact, in centering on experience as a means of imagining and articulating historical recovery and projecting futures, we are truly able to see how Afrofuturism is a movement that can be applied to a variety of works, genres, and subgenres produced across the Diaspora. This mirrors the growing diversity of contemporary expressions of Afrofuturism that are "emerging in the areas of metaphysics, speculative philosophy, religion, visual studies, performance, art and philosophy of science or technology" (Anderson and Jones ix). That is, thinking Afrofuturism in a myriad of expressions and aesthetic modes, and in a global, diasporic framework that takes into account shared heritage along with diverse socio-cultural experiences, permits this movement to be transformed into a pluriversality of transcultural, transborder and transdisciplinary voices, actors, and agents that challenges the stereotypical, alien, or absent representations of black lives, heritage, and presence in different spaces, and in turn projects "counter-futures" and "imagines alternative roles in the future" that are unique to their geo-political and cultural diasporic identity (Elia 84; Yaszek, “An Afrofuturist Reading” 299).

Therefore, in applying this theorization and expanded understanding of Afrofuturism to diasporic experiences across cultures, borders, disciplines, and genres, I suggest that this specific movement serves as a formative and foundation theoretical framework in which Black Speculative Arts in general, moves beyond place and genre, and "includes ALL people of the Diaspora, and places their culture, experiences, and THEM at the forefront of these imaginative works. For a people who have been told constantly that they have no history or future, that they can never be super or a hero, and that their very existence is a nightmare," Afrofuturism and Black Speculative Arts enable and empower black individuals and communities across the Diaspora to "imagine themselves outside of what the world has told them they must be" (Haynes “Black Speculative Fiction”).

\section{Afrofuturism Speaks Against the Denial of Afro-Mexicanidad}

In this essay, I charge us to engage the lens of Afrofuturism in its core projects and nuanced conceptualizations in order to examine cultural production produced in particular Afro-Diasporic spaces where black lives and black futures have not only been racialized and marginalized, but have been "deliberately rubbed out" (Dery, Flame Wars 180). This is the case of Afro-Mexican communities, who have been historically and socially removed as stakeholders in Mexico's present and future landscapes. Black lives in Mexico have been represented as alien at best, but utterly absent at worst. In fact, the historical amnesia and the denial of belonging and of the mere presence and futures of black identity in Mexico is so pronounced that it is common for one to hear the phrases "no hay negros en México" and "son cubanos," declarations that speak volumes about the relationship between Mexicanidad (Mexican national and 
cultural consciousness) and blackness. This racist disconnect between blackness and Mexicanidad also echoes within powerful social and cultural spaces. For example, Mexican cultural institutions and museums carve little to no space for the contributions of Afro-descendant populations in Mexico's history, current cartography, and future landscapes.

Even Mexico's most-famed expert on blacks in Mexico, anthropologist Gonzalo Aguirre Beltrán, who did extensive ethnographic work on Afro-Mexican populations, described the black presence as a "closed" pathway from Mexico's past to present. As he states in his seminal work, La población negra de México:

En la actualidad no existen en el país grupos verdaderamente negros...aún los grupos que hoy pudieran ser considerados como negros, aquellos que, en virtud de su aislamiento y conservatismo, lograron retener características somáticas predominantemente negroides y rasgos culturales africanos, no son, en realidad, sino mestizos...Es del consenso general que los esclavos que contribuyeron a dar color a la carga genética de México quedaron integrados en el mestizaje de modo tan completo que resulta difíficl, para el lego, distinguir los rasgos negroides en el conjunto de la población actual. Lo anterior implica aceptar que la integración negra es un hecho consumado en el tiempo histórico. $(7-8,277)$

This quote has a very poignant significance in relation to the tenets of Afrofuturism, which aims to recover histories and in doing so, project "counter-futures." Here we see how this foundational work has written black history out of Mexico's contemporary and future landscapes, framing it entirely within the narrative of colonial slavery (not enslavement), as we see in Aguirre Beltrán's text, rubbing blackness out of the present, and denying any future of black identity and agency in Mexico. Moreover, what is further concerning about this passage which denies black presence (and I would thus argue, futures as well), is that it is singularly Aguirre Beltrán's voice that defines black identity and black consciousness. There are no other voices heard in this imagination of blackness, nor visions of "how we see ourselves," which speaks directly to Marcus Haynes' reflection on the importance of Afrofuturism and Black Speculative Arts, as movements "for a people who have been told constantly that they have no history or future."

This marginalization of black voices in Mexico's history and the denial and invisibility of black presence can also be seen in official spaces of representation in the Mexican national census and in the Constitution. The year 2015 was the first censorial recognition of the black presence in Mexico, a year when the interim census finally added a category for Mexicans of African descent. Prior to this time, these populations literally have not counted. In addition, the approval of Constitutional recognition has only fully transpired in the year 2019, as a result of Afro-Mexicans and their allies campaigning vociferously for constitutional recognition, a move that would position these black communities as equals with other formally recognized ethnic groups, and would thus be afforded the investment and resources that come with juridical, constitutional standing. In essence, as a result of their own resistance and push for recognition, Afro-Mexicans are attempting to construct counter-futures through juridical and constitutional amendments.

Thus, as we consider the landscapes of Afro-Mexican identity and experiences at the intersections of historical denial, contemporary invisibility, and impossible futures, I argue that engaging Afrofuturism becomes a strategic tool with which to re-articulate, re-imagine, re-image, and re-position blackness in Mexico. More specifically, in analyzing films that I suggest serve as strategic tools with which to re-frame blackness in Mexico, and also speak to the objectives of Afrofuturism and Black Speculative Arts, we are able to recover Afro-Mexican histories, tell other stories, reflect upon diverse Afro-diasporic experiences, and construct counter-futures as a result of re-imagining the past, present and future and "altering the power dynamics that we are accustomed to in order to illuminate hidden histories and silenced voices" (Djèlí Clark).

As I will illustrate in this article, this means that not only is there a recovery of Afro-descendant voices and histories within contemporary Mexico, which in turn places these black communities and lives as members to be equally and equitably included within the frameworks of belonging in Mexico, but more importantly, this re-imagining of black history and the articulation of presence and belonging also facilitates a vision of futures, or "counter-futures" that project black stakeholders, powerbrokers, agents, and superheroes as integral to the future landscapes of this particular geo-body and geo-political space. This essay engages these broader, central objectives of Afrofuturism and Black Speculative Arts, and applies them to a particular AfroDiasporic experience, that of Afromexicanidad.

\section{Visualizing a Future Denied: The Erasure of Blackness in Mexican Cinema}

Through the dominant logic of mestizaje that has pushed blackness aside in Mexico in order to privilege whiteness and whitening, we can reflect upon the estranged place of blackness in Mexican popular culture, particularly film. Specifically, we can observe how these visual spaces have echoed this logic and located black lives and black identity elsewhere, limiting representation to marginal and anachronic spaces, or completely erased from the Mexican geo-body. For example, if we look to perhaps the most formative and economically vibrant era of Mexican film production known as the Edad del Cine de Oro, or Golden Age 
of Film (1933-1964), we can clearly view the alien-ness and dystopic relationship that marks the connections between blackness and Mexicanidad. This time period is labeled as a "golden age" for its prolific productions and global successes in cinematographic arts, so much so that the film industry was Mexico's third largest contributor to the economic sector by 1947 (Fein 103). However, I bring this particular moment into the conversation because it is perhaps the most influential time period in imaging and imagining narratives of Mexicanidad that aligned with State projects to unify the country following the Mexican Revolution. In fact, Marco Polo Hernández Cuevas labels this period as the "cultural phase of the Mexican Revolution," precisely due to the strategic use of arts and culture to reflect the national imaginary of cohesion after the tumultuous social divisions and fragmentation of Revolution. Thus, it is no wonder that during this "Golden Age" we see a visual push for cohesion that is imbedded in a cinematographic mirroring of the logic of mestizaje, when characters and protagonists literally reflect the national image that speculates Mexico's future reliance on the importance of maintaining an affinity towards ethno-racial mixture. However, it is also within this filmic imaginary that we can simultaneously observe a bending towards whiteness/whitening, and a marginalization of blackness. For example, in the highly popular film Angelitos negros (1948), we observe the uneasy preoccupation with racial mixing and its connection to national identity, as it plays out in the home of a wealthy and successful actor, played by the iconic Pedro Infante, and his wife, a school headmaster, played by the charming blond actress, Emilia Guiú. The film outlines their romance, but more so highlights the question of blackness in Mexico's genetic and historical past. That is, the film attempts to respond to the question of what to do with the "black grandma in the closet" (as referenced by Henry Luis Gates, Jr. in his film series "Black in Latin America"). This aspect of the plot unfolds when the child that is born to these main characters is a mulata. Her mother (Guiú) rejects her, questioning this "mala sangre" and asking "Por qué Dios no me dio una hija blanca y rubia?" What we later learn is that the black maid Nana, played by Rita Montaner, was actually Guiú's mother. When this truth is revealed, the characters played by Guiú and Montaner clash, with Guiú's character violently striking her "Nana," thus causing this helpless maid/mother to fall down the stairs, and eventually succumb to her injuries. Guiú's character does eventually accept her familial heritage, and her dark-skinned daughter, a symbolic nod to the acceptance of blackness within Mexico's family tree, albeit, after an act of violence forces her skeptical reconciliation with her ethno-racial heritage.

What I would like to highlight here is that the speculative nature of this scene in which the black character eventually dies, reflects the dominant logic of mestizaje in which blackness has ended, and faded into brown or whitened through mixture (the mulata grandchild of Nana). And, while the protagonists ultimately accept the link to this black grandma in the closet, she is clearly represented as an alien figure in Mexico's familial present, and excluded from the image of the national family's future. Hence, she dies. This echoes the strategic State narrative of that era following the Revolution, aimed to silence separate and fragmented ethnic identities as a result of the assumptions that Mexican society "had been divided by years of discrimination that now needed to be put behind, and that the priority at the time was for the nation to be one" (Serra 135). In essence, within the mestizo backdrop to post-Revolutionary unification, black voices are silenced and black lives are denied as protagonistic stakeholders in this cinematographic projection of Mexico's future family, which itself aimed to serve as a mirror to Mexico's actual future as a nation.

Furthermore, we can also see this alien-ness and dystopic relationship between blackness and Mexicanidad in the fact that all of the actors that played Mexican black characters used blackface in the film. That is, both the Nana (played by Rita Montaner) and the mulata child used blackface, an interesting detail especially in the case of Montaner, who herself is of Afro-Cuban descent. This brings up the question about the cinematographic need to "darken" characters of African descent, even those who do align themselves with this heritage (Montaner). Moreover, it is telling that the black Mexicans donned blackface, alluding to the notion that no Afro-Mexican actors were available to fill these roles. ${ }^{1}$ Needless to say, we do "encounter" other black characters in the film, who play the roles of Pedro Infante's band members from Cuba. ${ }^{2}$ However, these secondary characters do not don blackface. I suggest that their "Cubanness" permits a different association with blackness as opposed to the Mexican association with blackness. To be a black Cuban is possible. To be a black Mexican is not.

This notion of the black presence in Mexico as being of Cuban origin is similarly found in the film $\mathrm{Al}$ son del mambo (1950), a production that traces the comic adventures of three Mexican musicians who travel to Cuba to find rhythmic inspiration. The urban musicians travel in a mule-driven cart in search of a primitive and rural landscape, where "se respire un aire puro" in the "País de la vida." This lens that frames the rural countryside as primitive and pure is where their musical inspiration can be found, surrounded by the sensual dancing and exotic rhythms of the countryside's inhabitants. These inhabitants are black, and led by the iconic Cuban bandleader and musician, Dámaso Pérez Prado, the "King of the Mambo." The central Mexican protagonist, Roberto Dávila, who is played by Roberto Romaña, is fascinated by the primitive rhythmic sounds, despite his critique of their lack of finesse and logical organization. He describes the music as a "ritmo distinto, formado por los elementos más primitivos y sencillos de la naturaleza que excita e incita a la alegría y a la danza." Here we can observe how 
the characterization of the music and the black musicians and black island inhabitants is framed as fetishized elements that belong within a primitive space. I would like to point out that this is very similar to Vasconcelos' characterization of black identity in the La raza cósmica, "el negro, ávido de dicha sensual, ebrio de danzas y desenfrenadas lujurias," which also fetishizes blackness and aligns it with exoticism as expressed through sensual dance and unbridled lust (61). Thus, while this imaginary of blackness is not one of denial and rejection as we can see in Angelitos negros, it does fit the racist stereotyping of blackness as primitive, exotic, and fetishized by the white male gaze that is represented by the three Mexican musicians.

In the end, Dávila takes on a managerial role, agreeing to connect Pérez Prado and the other black Cuban musicians with his wealthy Mexican business associate who will contribute the necessary funding needed to "save" the Cuban compound from impending closure. Thus, not only do the light-skinned Mexicans "discover this exotic and primitive music and refine it to serve more civilized tastes, but their characters also serve as figures who rescue the rural, black musicians from financial doom. That is, the Mexican adventurers paternalistically guide the black Cubans out of their "arrested development toward their idealized form of social and cultural progress" (Garcia 517). Within this overall framework, I suggest that we can again observe the logic of mestizaje playing out in a cinematographic representation of the speculative futures of blackness that must "leave behind [its] own backwardness," and be guided out and saved by whiteness (Serra 139).

Despite the fact that Angelitos negros and Al son del mambo debuted more than 65 years ago, I would argue that both films serve well in representing what was and what has become and still is the most common and dominant cinematographic landscapes of blackness in Mexican film. They are landscapes in which an uneasy gaze looks upon black bodies and black lives, not knowing what to do with them, and often rejects the black blood that runs through its national family's past and present (Angelitos negros). And, if finally accepting the inclusion of the historical, cultural, or genetic lineage of blackness, it is male whiteness that serves to "discover," tame, civilize, and rescue these black bodies. These tropes are equally as present today as in the film production of this Golden Age. In fact, blackness is more absent in today's cinematographic landscapes, and are most commonly represented in period-pieces (harkening back to the colonial era), in which black characters exclusively play the role of servants and slaves. This is very common in contemporary Mexican telenovelas, and continues the placement and roles of black characters singularly within "occupational frames, as servants, comedians, musicians and dancers," thus reflecting the notion of a supposed "natural racial order" in a society that links race, economy and occupation (Pieterse 124). In turn, the film industry in Mexico has echoed and reinforced the role of the light-skinned, paternalistic State that, despite its attempt to ease the nation's tensions via the visual and social discourses of ethno-racial and cultural mixture and unification (mestizaje), black agency and the voices of black lives have continued to be suppressed, distanced, and silenced, absent as stakeholders and power-brokers in framing Mexicanidad in its contemporary and future articulations.

\section{Re-framing Black Presence and Futures in Contemporary Mexican Film}

We have observed how these tropes of fetishization, stereotyping, alienation, marginalization, and invisibility have limited or silenced black protagonism in Mexican film production. However, at this very strategic moment, especially within the last five years, in which the calls for the recognition, articulation, empowerment, and celebration of Afro-Mexican lives, heritage, culture, and consciousness have grown and strengthened, we are also able to observe how very recent cinematographic production is now, finally, after all these decades, aiming to challenge, critique, undo, transcend, rearticulate, and reposition the presence and the futures of black identity in Mexico. In fact, as visual technoculture has merged the access of visual production with the reach of global audiences through digital platforms such as YouTube, we have seen a shift in the framing of Afro-Mexican lives, culture, and history. From formal productions created by researchers at culture institutes such as the Instituto Nacional de Antropología e Historia (INAH), and universities such as the Universidad Nacional Autónoma de México (UNAM), to videos produced and uploaded by community activists and local musicians and artists, the presence of Afro-Mexican protagonism and visual agency has increased enormously over the last decade. YouTube searches reflect this growing database of visual technoculture that aims to reconstruct and strengthen black voices and black agency. In fact, we can clearly note the interest in producing and accessing these sites and productions not only as a means to disseminate information about these communities, their history, culture, and daily lives, but also to carve a space in which black stakeholders are re-claiming their place and space in Mexico's cinematographic and visual-cultural landscape. Equally important, I would argue, is that this shift in the representation of blackness in Mexico is precisely mirroring and echoing the tenets of Afrofuturism and the Black Speculative Arts Movement, as Afro-Mexicans are now able to not only see themselves, but also to "imagine themselves outside of what the world has told them they must be" (Haynes). Seeing oneself is so critical in deconstructing a history and presence marred by invisibility. And to imagine "counter-futures" and to tell other stories is now strengthened, as the spaces of visual production have opened up 
avenues in which to express, re-image, and re-imagine black history, culture, and identity in Mexico.

Two recent films that re-frame the relationships between blackness and Mexicanidad are Artemio (2017) and La negrada (2018). Both films connect with Afro-Mexican communities in Mexico's Costa Chica region along the Pacific coast, La negrada being the first full-length feature film to include an all-black cast. In addition to framing the specificity of black lives within this region, these films combine general thematic narratives such as freedom, love, and perseverance with the challenges and re-thinking of the discourses of belonging, difference, and self-consciousness. Produced and directed by Jorge Pérez Solano, La negrada mixes documentary-style segments with a fictitious plot that successfully tells the stories of contemporary Afro-Mexican lives through the fictional relationship between two best friends, Juana and Magdalena, who share the love of the same man, Neri. The film not only trails their estranged relationship, but also the connections between their extended families-grandparents and children-thus, presenting an intricate view and vision of multi-generational experiences that ring true to contemporary Afro-Mexican lives.

The shared love of Neri between Juana and Magdalena, who both have children born by him, reflects the occurrence of polygamist-style relationships and co-parenting that are common in this coastal region. Known as "el queridato," where a man has his main house with a wife, but also resides and has children with other women, this relationship structure is often the result of economic hardships and the frequency of migration in and out of this region, especially by men. As women are often left to fend for themselves in terms of securing income sources and child-rearing support, I would argue that this style of socio-economic relationship has served as a survival mechanism, providing families and especially single mothers with a collective support network in which the proportion of males to females is often uneven. It is interesting to note how the film projects different gendered and generational viewpoints towards el queridato and co-parenting. For example, the film echoes male perspectives that place no negative judgment on this form of marital relationship and cohabitation. After Juana's sickness and eventual passing, Magdalena asks Neri if he will now finally come to live with (or even marry) her. His response is one that disregards her question/request, as he states, "Mientras yo cumplo aquí, no tienes porque decirme nada. Así ha sido y así será." That is, as long as he continues to provide for her and their children that they share together, the idea of monogamy has no place nor need according to him. Magdalena is obviously angered and hurt by his response, lashing out at him for continuing to begin new relationships with other women, and stating, "Tú quieres seguirte cabrón." Even the younger males of the community share Neri's perspective. As the young women critique Neri for being with five women along the coast and having children with all of them, their young male friend, Noe says that he will also be like Neri when he grows up, since "la tradición no se pierde tan fácil."

In addition to the incorporation of this real-life portrayal of contemporary marital and parental relationships in these communities, the inclusion of other realistic elements of Afro-Mexican life also abound throughout the film. Beautifully detailed frames of common community occupations such as those connected to the fishing and tourism industries, similarly intersect the fictitious storyline. In fact, we see the intergenerational collaboration between grandparents, parents, and grandchildren in fomenting economic well-being, or just plain economic survival. For example, several cuts include grandmothers and their grandchildren working together in the family's beach-side restaurant, or sons and fathers diving and fishing together to gather the catch-of-the day and sell it at local markets. The fishing industry is of vital importance to these communities along the Costa Chica. Moreover, the film also includes several references to important traditions in Afro-Mexican communities, such as that of the tono/tonal, a concept that connects humans and animals in a spiritual bond. It is said that when a person is born, they are assigned a tono or tona, an animal that is forever linked to them. If the animal gets sick or dies, so does the person, and vice versa. I posit that this concept constructs an important philosophical and existential relationship between humans and nature, one in which the mutual care of each other is necessary for the survival of both. Magdalena's mother illuminates the tradition of the tona/tonal, bringing the history of this important concept to bear on the present identity and cosmology of AfroMexicans: "Ellas tenían ideas viejas, y cuando tú naciste, querían que tuvieras tu tona, tu animal guardián, el que te ayude y te cuide toda la vida." In addition to recounting stories of the character's tona, it is further effective and unique how the film also uses this concept as a means of understanding, narrating, and envisioning the interconnectivity between Magdalena and Juana, whose relationship is one of a similar, symbiotic connection. As Magdalena's mother continues, "Hay veces que eso de la tona se cumpla y otras no, pero en esta historia, una sola cosa está clara, tu destino y el de Juanita están unidos desde que nacieron. Están tan unidos que tienen el mismo gusto y quieren al mismo hombre, y que quién sabe lo que vaya a pasar cuando ella [Juana] se muera." Here we see how the concept of the tono is used as a framework to understand the interconnected relationship between these two women and their mutually dependent destiny.

Furthermore, the film also includes segments that reference that discrimination faced by Afro-Mexicans on a daily basis. A poignant scene takes place when Sara, Juana's and Neri's daughter, travels to another city in search of homeopathic medicine for her ailing mother. On the bus ride back to her home, the bus is stopped by officers at a 
migration checkpoint, a common occurrence that often takes place throughout Mexico as a security measure. Sara is one of the few passengers who is ordered off the bus. One of the officials looks at Sara and states, "Tú no eres mexicana, ¿verdad? ¿De dónde vienes, negra? Me van a cantar el himno nacional desde el 'más si osare'." At this point in the film, Sara starts singing this particular segment of the Mexican national anthem, a common reality and actual experience that Afro-Mexicans recount as they travel throughout the country. Her singing is followed by alternating images of the different faces of Afro-Mexicans, as if they were passing through a cinematographic representation of a police line-up. I suggest that this scene not only reflects the harsh reality of Afro-Mexicans in the fact that their place and belonging within the nation is consistently questioned or outright denied (an echo of what I previously describe earlier in this essay), so much so that their belonging is criminalized: they are viewed as foreign, cubano, illegally present in the county, and thus must prove not only their legitimacy, but also their Mexicanidad, by singing the national anthem.

In fact, this film introduces the topics of discrimination and race/racialized consciousness from the very beginning, as it starts with a written definition of the term "la negrada." It says that it is a "término que los negros se aplican a sí mismos, surgió del disgusto que les produjo y produce el descalificativo racial." I posit that the interjection of this definition at the very start of the film not only serves to position the (re)framing of blackness front and center, but to also interrogate the representations of blackness from various vantage points, especially in terms of its relationship to AfroMexicans themselves, and to Mexico's present and future landscape. In an interview in which the director describes his own Indigenous background and his own feelings and experience of being "excluded in my own country," the reasons for him creating this film include the desire to "create awareness of marginalized sectors of our society. I make these communities visible in my films. My intention was to make a film to raise awareness of the plight of AfroMexicans to increase their visibility and start a dialogue about our national identity" (Jappie). As we can see, the film clearly makes visible the marginalization and discrimination that Afro-Mexicans experience in their daily lives. However, it also inserts an ownership of blackness from within these communities, a re-articulation and reification of what it means to be negro/a in Mexico according to Afro-Mexicans themselves, and a representation and communication of the histories, stories, and traditions that are shared among these communities (for example, the foregrounding of the concept of el tono/tonal), which in turn project counter-futures in which they are no longer invisible and discriminated against. Instead, the film includes various instances where recognition, resilience, and empowerment are foregrounded. For example, when Sara walks through the local bus terminal, she passes by another young woman who is handing out flyers about the fight for constitutional recognition. She sings out to the crowds passing through the terminal,

Les estamos invitando para que se unan a nuestra lucha para obtener el reconocimiento jurídico de los pueblos afromexicanos en la Constitución Mexicana. Hermanos, asistan al séptimo foro de la negritud en donde escucharemos lo que cada uno de ustedes tiene que decir para lograr la atención y el reconocimiento que nos han negado.

It is true that several foros or town halls and forums have been held throughout the Costa Chica in order to boost support for the fight for the Constitutional recognition that they have historically been denied.

Similarly, throughout the film and especially at the end, several Afro-Mexican elders recite versos costeños, or poetic verse, that are common oral traditions and past times in these communities. A verso sung by Magdalena's mother towards the end of the film is as follows: "Si por negra me desprecia, no desprecia mi color, porque entre perlas y diamantes esta negra es la mejor." This poetic recitation acknowledges the way Afro-Mexicans have been looked down upon, yet simultaneously re-positions blackness and color consciousness into a frame of empowerment and beauty, whose value is "like pearls and diamonds, this black woman is the best!" In other words, Black is beautiful.

Moreover, it is interesting to note the intersectionality of race and gender in this film, especially in relation to the role of women. I suggest that it is the fictional story of Magdalena and Juana that reflects so poignantly upon the realities of Afro-Mexican life---from socio-economic hardships and marital relations, to entrepreneurship and sustainability. In fact, I would argue that it is the role of women in this film that offer the most powerful visions of presence and place in these communities, and of counter-futures as well. We see the innovative entrepreneurship of Magdalena, who through her own resourcefulness, is able to purchase a refrigerator for their house and business. The women elders also represent a stance of strength against the challenges of daily life, singing versos throughout the film and reminding their adult daughters to rely on each other and the networks that they have forged in order to support their families. Furthermore, we see a clear counter-future through the eyes of the young women, the younger daughters, who challenge concepts such as el queridato, clearly holding this relational practice in a negative light. And finally, Sara, Juana's daughter, who refuses to accept her madrina's offer to lend her money in exchange for Sara being impregnated by her madrina's husband. While Sara needs money in order to pay for her mother's medical treatments, she takes a stand against her madrina's choice of repayment. The madrina has asked her to be impregnated by her husband since the couple cannot have children of their own. By doing this, it would serve as 
a repayment of the money lent to Sara by her madrina. In her strength and self-determination, Sara refuses to commit to this pact. In essence, this young woman re-imagines her future: she will not be sexually exploited as a loan repayment plan. Nor will she follow the pathway of many other young women in these communities, who become mothers at a young age. Sara, as she states it, will find another way, using the cosmetic business that she runs to forge a different trajectory, a counter-future, one of empowerment and self-determination.

This vision and expression of counter-futures and black women's empowerment and self-determination, together with an exploration of blackness and belonging are equally prevalent in the other film that I will discuss, Artemio, produced and directed by Sandra Luz López Barroso. This international award-winning short film is not a fictional feature, rather a weaving together of documentary-style segments that tell the story of a young boy, Artemio, who was born in the United States and goes to Mexico with his mother, Cocco Zárate. After living as an undocumented immigrant in the United States with Artemio and her two other, older children, Cocco is deported back to Mexico, and returns to her small, rural hometown of Cacalote, Guerrero, also located in the Costa Chica region. When Cocco returns to Mexico with Artemio, she adds a baby daughter to the family that is born out of her relationship with her boyfriend Luis, who also lives in Cacalote.

Similar to La negrada, this film also presents a beautiful cinematographic perusal of the Costa Chica, and the small black towns that cradle Afro-Mexican lives along the country's Pacific coast. Numerous scenes present glimpses of daily life in this region, from the maternal homemakers busy in their daily routines, to farming, and the slower pace of rural past times, something that is a challenge for Artemio, whose only frame of lived experience is the busy, cosmopolitan culture of his life in the United States. Now in rural Mexico, he has to contend with constant power outages that leave him wistfully wandering around the house or just playing fútbol outside. He cannot play the video games that he wants, "se fue la luz otra vez." Life definitely is different in Cacalote, especially for Artemio. The film allows us to follow him through this exploration of difference, newness, and questioning belonging, as he learns about and is exposed to Afro-Mexican daily lives and traditions. For example, we join him and his baby sister and mother as they walk home one evening. As the sun sets, they pass by a house that seems to be having a party. Traditional music is playing in the distance as house guests sit along the edges of the house's patio. Artemio asks Cocco, "Why are they celebrating?" And she answers,

They are not celebrating. Actually someone died there. But it is a celebration because, uh, it's like when someone dies, in your house you have to bring the music to celebrate that this person passed to another realm, to another stage. So, it's a sad episode but it's happiness too, because it's advancing spiritually, going forward, So it's something good.

Here we can observe a teaching moment, when Cocco serves as a cultural translator for Artemio as he learns about the unique traditions of this Afro-Mexican community, particularly about their customs as related to death and dying. As Cocco continues to explain, "Dying is not totally bad. It's something good because it means that you already completed your mission here on earth, so you're ready to move on to the next stage. Sad but good at the same time."

We also accompany the family to a local wedding, joining the celebration, watching Artemio uncomfortably wade through the dancing guests, and bride and groom, as typical music, banda and chilenas, play in the background. Artemio's discomfort once again is a result of his lack of familiarity with the customs and the people of this small town. His mother does her best to foster a sense of belonging, teaching him and explaining the customs. It is fitting that Cocco plays the role of a cultural ambassador and translator, for in actuality her grandmother was one of the most famous dancers of the son de Artesa, a dance and music style that is perhaps one of the recognized and celebrated art forms that is unique to AfroMexican identity in the Costa Chica. Catalina Noyola Bruno, fondly known as Doña Cata, was Artemio's great-grandmother, Cocco's grandmother, was known throughout the region as one the last great Afro-Mexican "bailadoras" of this particular style of music and dance. Even into her late years, with limited strength and mobility, Doña Cata would ascend upon the wooden artesa and pound her feet with such strength and prowess, matching the rhythmic beat or son that accompanies the baile de la artesa. It was during an interview with Doña Cata that the director/producer, Sandra Luz López Barroso, was able to meet the extended family, particularly Artemio and Cocco. In fact, in getting to know Cocco, the director/producer was mesmerized by this granddaughter's life stories, her travels across the globe, and her hopes and dreams. It was then that this project and film was conceived. When López Barroso speaks of Cocco and her young family, she shares that "Me pareció que había encontrado a una Doña Cata joven...Sería ella la que contenía todo aquello de lo que quería hablar: las mujeres afros, costenas, fuertes, sensuales, independientes" (Bacilio). Similar to the other Afro-descendant women portrayed in La negrada, Cocco Zárate also most definitely reflects the strength, resilience and self-determination of black women in Mexico, forging a new life for herself in Cacalote after deportation, serving as educator and strong-willed matriarch to her son and new baby daughter, and always thinking ahead in her pathways to accomplish her goals for a better life for herself and her family. 
Thus, the film Artemio also presents us with a re-framing of Afromexicanidad, learning about the specificities of daily life, the customs and traditions lived throughout the black towns in the Costa Chica, and the nuances and challenges of these communities. At the same time, the film also sheds light on experiences that are shared among Mexicans across the country, regardless of heritage and ethno-racial background---those experiences related to migration and the transborder/translingual identities that are now very much a part of the fabric of Mexicanidad in general. We sense an uneasy restlessness throughout the film, both by Artemio, his mother, and other characters as well. This restlessness is a reality that not only matriculates in the Costa Chica, but also abounds throughout the country as individuals contemplate and engage the option of migration in search of more opportunities and a better life. This aspect of Afromexicanidad and Mexicanidad is addressed from the very beginning of the film, when Cocco is speaking with a family friend about her plans to move on from Cacalote to Cancún in search of a better job and future. In this conversation, her friend concurs with Cocco's plans to move at the end of the month, "La cosa es ésta, si te vas a mover de allí es bueno, es bueno porque en el monte no haces nada y él [Artemio] tampoco...Qué bueno, digo que sea bueno para mejorar porque él necesita estar fuera de este monte." To which Cocco responds, "Todos, todos en algún momento necesitamos salir." This notion that "we all" need to leave at some point paints a very poignant and realistic picture of the feelings and perspectives toward migration within Mexico and beyond its geopolitical borders, especially for those in poor, marginalized, and rural settings, where underdevelopment continues to mark the socio-economic landscape throughout the country. Moreover, during the film's climax and turning point, this issue of staying or leaving comes up again, now in a conflictual nature, when Cocco has a fight with her older daughter, Sharlyn, about Artemio's planned return to the United States. Sharlyn expresses her anger and frustration with her mom in this scene, stating that she is working multiple jobs so that she can earn enough money to help bring Artemio back to the U.S., as they had originally planned. However, Cocco exclaims that at this time he does not want to go back, he wants to stay in Mexico with her, and she cannot force Artemio to return there to live with his older siblings. The shouting match ends as Sharlyn hangs up, cutting off the dialogue across geographic borders that has been made possible by an old telephone that has served to connect the family while they are geographically segregated. This climactic turning point reveals the raw emotions that accompany migration and family separations. Artemio immediately calls his sister back. While we never see or meet Sharlyn in this film, we get to know her through these telephone calls, and in this moment we can hear her sobbing and can sense the sadness and challenges that come with these aspects of movement and migration. Artemio asks her,
“Are you crying for realzies or are you crying for liezies?" She replies, "No, I'm crying 'cause I miss you and I want to see you." Thus, through these dialogues, we are able to access the feelings and experiences that run across the lives in consistent flow or plan of movement. Similarly, towards the end of the film, Artemio asks his mother about their plans to move to Cancún. He did not realize that they would be moving so soon, and he subsequently asks if they will be able to return to Cacalote... and to Utah as well. Cocco responds to his inquiries, "Claro que vamos a regresar [a Cacalote]... No estoy muy segura de Utah, pero si todo sale bien, vamos a encontrar la forma de conseguir mi visa y vamos a regresar." These declarations and the questioning about returning to one's homes (home in the plural sense as it takes on a notion of multiple networks of being and belonging due to this constant migration) reflect the realities and challenges of lives intimately linked to patterns of migration. At the film's close, both Cocco and Artemio sing the popular children's song "Down by the Bay." The lyrics echo this restlessness, this uneasiness of belonging, which simultaneously seems somewhat natural to those who live with this notion of "el irse o el volver," (Bacilio). The lyrical exchange goes as follows:

\section{Cocco. ¿ ¿Te recuerdas la canción que cantamos el otro día?}

Artemio. No.

Cocco. "Down by the Bay.” ¿Qué te parece si la cantamos ahorita? ¿Sale? Tú empiezas y yo te sigo porque no me recuerdo cómo empieza.

Artemio. [Singing together with Cocco] Down by the bay, where the watermelons grow, back to my home, I dare not go...

This very poignant line closes the film, leaving the viewer with the sensation of sadness mixed with hope, taking on a role as witness to the adaptability and strength that marks these characters, individuals, and families that lead lives of migration or constant movement.

I suggest that López Barroso successfully represents the macro and micro identities and experiences of Afro-Mexican communities. Her film, which she classifies as "cine documental," where "la realidad siempre supera cualquier expectativa o plan de rodaje," makes visible the intricacies of daily life and serves as a visual testimony of the customs, traditions, and experiences of black lives in the Costa Chica (ibid). Furthermore, similar to La negrada, it also offers a speculative glance and vision of futures: futures that connect with migration and wandering, futures that look to opportunity and innovation, and futures that engage transborder and translingual identities (the dialogue in this film easily 
alternates between Spanish and English, requiring a certain level of bilingualism on the part of the viewer).

\section{Conclusions: An Afrofuturistic Re-framing of Afromexicanidad:}

As we observe in both films, La negrada and Artemio portray a re-framing of Afro-Mexican lives and a re-articulation of the cinematographic representations of blackness in Mexico. Both works offer much more comprehensive, in-depth, and nuanced visions of these communities, their histories, customs, worldviews, challenges, hopes, and dreams. I would argue that these cinematographic landscapes of blackness in Mexico as represented in these two films bring into focus the fact that these lives have been "rubbed out," denied, rejected, and marginalized. And in doing so, both La negrada and Artemio critique and re-frame the historically uneasy relationship between blackness and Mexicanidad. That is, both films position black lives and black identity as so much more than a stereotyped, fetishized, and alienated construction, which we have commonly seen in other popular films, such as in Angelitos negros and $\mathrm{Al}$ son del mambo, from an era in which cinema so strategically and profoundly marked national consciousness and influenced how black heritage has long been framed and represented in Mexico film and society.

La negrada and Artemio speak against and undo the longstanding subaltern placement of blackness in Mexico. Simultaneous, they also present a telling of and visualization of other stories, as told by and through the voices of AfroMexicans themselves, thus addressing the broader questions of voice and agency (power-brokers and stakeholders and Dery delineates), which lie at the core of Afrofuturistic projects. Moreover, both of these films also echo the calls of other artists that are engaging and expanding upon Dery's conceptualization of Afrofuturism and Black Speculative Arts in order to interrogate, critique, and re-frame the status quo of black communities and black lives in diverse geopolitical locations and in a variety of global contextual and cultural spheres. That is, while neither film falls within the genres of science fiction and thus do not exactly match Dery's original notion of Afrofuturism as "speculative fiction that treats African-American themes and addresses African-American concerns in the context of twentieth-century technoculture", these films do indeed reflect the nuanced and extended definitions as described earlier in relation to the theorizations of Eshun and Yaszek: they tell other stories, foregrounding experience and the diversity of Afro-diasporic lives; they rescue these stories and histories, which have been denied and hidden; and in turn they offer a re-imaging and re-imagining of black history, black presence, and black counter-futures ("Black to the Future" 736).

Finally, I would also suggest that the films Artemio and La negrada serve as very effective examples in thinking about the unique expressions of Afro-futurism in a Mexican context. For communities of African descent in this country, futures are very much tied to current-day demands for socio-political recognition. That is, the fact that these films foreground the declarations by Afro-Mexicans that, "we exist, we see ourselves, and that you see us," both La negrada and Artemio serve as very effective examples of imaging and imagining the building of futures based on the full and equitable participation and inclusion of Afro-Descendants in Mexico's present. The characters, plots, and themes that are woven throughout these two works push the question of recognition to the forefront by creatively and strategically building upon notions of self-consciousness, self-reflection, and self-recognition that are represented in ways that envision black futures in this particular geopolitical space that has historically denied their presence and contributions. Both La negrada and Artemio present us with an Afrofuturistic re-framing of Afromexicanidad: their respective use of imagination and creativity serve a "sources of hope and transformation," in which the "potential for a different future is brought forward to consider" (Johnson Lewis, "Afrofuturism: Imagining an Afrocentric Future"). Now through the visualization and representation of these Afro-Mexican voices, stories and histories, we see black protagonists, stakeholders, mothers who are superheroes, and youth who challenge racialized, prescribed visions of themselves, and instead "imagine themselves outside of what the world has told them they must be" (Haynes).

\section{NOTES}

1. The use of blackface during this era of Golden Age Cinema can also be observed in the film La negra Angustias (1949), another excellent example in which Mexican actors were "darkened" in order to play the role of a Mexican of African descent. This film, which is based on the novel by the same name written by Francisco Rojas González in 1944, similarly takes on the notion of revolutionary heroes that uphold the fight for national unity during and after the Revolution. In this film, which was adapted by a female director, Matilde Landeta, it is a mulata heroine that takes the charge to fight for the poor and marginalized populace. However, despite her blackness being strategically deployed as a tool of rejection and marginalization (for example, because she 
is black she is rejected by the light-skinned man whom she admires), her "blackness in both the novel and the film gets lost in the rhetoric of Mexican nationalism and class struggle" (Arce 1086). That is, race, particularly black identity, is subsumed into class struggle, and becomes a product of the nationalistic logic of mestizaje in which racial difference is ultimately submerged into class difference as a result of this rhetoric of cosmic mixture. This has also been a dominant narrative tied to the Mexican Revolution: that it was not about race/ racism, but purely about class and class struggle. Clearly this does not engage the intersectionality of race and class. Moreover, when the director herself was asked about making a feature film about a black Mexican, she "claimed that the role played by blacks in Mexican history and culture was insignificant, a fact supported by her choice of a non-black actress who wore blackface" (Arce 1087).
2. The inclusion of Cuban musicians and Cuban popular music styles was common and highly influential in the films of this Golden Age. For example, in the film Al son del mambo, Rita Montaner (an actress but renowned Cuban singer as well) in addition to the "Mambo King" himself, Dámaso Pérez Prado, both highlight the famed contributions of Cuban musicians in the Mexican film industry of this time period. This influence even extended to the popularity of the more specific cine de rumberas sub-genre, which incorporated Cuban and other Afro-Caribbean music and dance styles. The Cuban actress Amalia Aguilar, who also starred in $\mathrm{Al}$ son del mambo, was known for her contributions to this sub-genre.

\section{WORKS CITED}

Aguirre Beltrán, Gonzalo. La población negra de México. Estudio etnohistórico. México, D.F., Fondo de Cultura Económica, 1989.

Anderson, Reynaldo. "Afrofuturism 2.0 and the Black Speculative Arts Movement. Notes on a Manifesto." Obsidian: Literature and Arts in the African Diaspora, vol 42, no. $1 / 2,2016$, pp. 228-236, 269.

Anderson, Reynaldo and Charles E. Jones, eds. Afrofuturism 2.0: The Rise of Astro-Blackness. Lanham: Lexington Books, 2015.

Arce, Christine. "La Negra Angustias: The Mulata in Mexican Literature and Cinema." Callaloo, vol 35, no 4, 2012, pp. 1085-1102.

Artemio. Directed by Sandra Luz López Barroso, Centro de Capacitación Cinematográfica, 2017.

Bacilio, Mario. "Los caminos hacia Artemio. Entrevista con Sandra Luz López Barroso, directora de Artemio." Ambulante, 12 Jun 2017, https://www.ambulante.org/ en/2017/06/los-caminos-hacia-artemio/.

Beifuss, John. "'Black to the Future'--Afrofuturism Comes to Memphis." USA Today Network, 13 April 2018, https:// www.commercialappeal.com/story/news/2018/04/13/ black-future-afrofuturism-comes-memphis/508768002/.

Combs, Sean. "Chadwick Boseman." Time. The World's 100 Most Influential People, 2018, http://time.com/ collection/most-influential-people-2018/5217574/ chadwick-boseman/.
Dery, Mark. "Black to the Future: Interview with Samuel R. Delany, Greg Tate, and Tricia Rose," in Flame Wars: The Discourse by Cyberculture, in The South Atlantic Quaterly, vol. 92, no. 4, 1993, pp. 735-778.

---. Flame Wars: The Discourse of Cyberculture. Duke University Press, 1994.

Djèlí Clark, Phenderson. How to Spite a Racist Troll: Support Black Dreams. 11 April 2015, https://pdjeliclark.wordpress. com/2015/04/11/how-to-spite-a-racist-troll-supportblack-dreams/ Accessed 21 March 2019.

Elia, Adriano. "The Languages of Afrofuturism," Lingue e Linguaggi, vol 12, 2014, pp. 83-96.

Eshun, Kodwo. "Further Considerations on Afrofuturism," CR: The New Centennial Review, vol. 3, no. 2, 2003, pp. 287-302.

Fein, Seth. "Hollywood, U.S.-Mexican Relations, and the Devolution of the 'Golden Age of Mexican Cinema," Film-Historia, vol 4, no. 2, 1994, pp. 103-135.

Fitzpatrick, Alex. "It's Not Just Black Panther. Afrofuturism is Having a Moment." Time, 20 April 2018, http://time. com/5246675/black-panther-afrofuturism/.

Garcia, David F. "Going Primitive to the Movements and Sounds of Mambo.” The Musical Quarterly, vol 89, 2007, pp. 505-523.

Haynes, Marcus. "Black Speculative Fiction. Where Elementals Meet Ratchedemics." 2019, http://www. mhaynes.org/black-speculative-fiction-definitions. Accessed 21 March 2019. 
Hernández Cuevas, Marco Polo. African Mexicans and the Discourse on Modern Nation. Lanham: UP of America, 2004.

Jappie, Zayyan. "An Interview with the Filmmaker Behind 'La Negrada '-The First Feature Film Starring an All AfroMexican Cast." Okayafrica, 23 Aug. 2018, https://www. okayafrica.com/an-interview-with-the-filmmaker-behind-la-negrada-the-first-feature-film-starring-an-allafro-mexican-cast/

Johnson Lewis, Jone. "Afrofuturism: Imagining an Afrocentric Future. Rejecting Eurocentric Dominance and Normalization." ThoughtCo, 19 Feb. 2018, https:// www.thoughtco.com/afrofuturism-definition-4137845

La negrada. Directed by Jorge Pérez Solano, Tirisia Cine, 2018.

Lao-Montes, Agustín. "Afro-Latin@ Difference and the Politics of Decolonization.” Latin@s in The World-System. Decolonization Struggles in the 21st Century U.S. Empire, edited by Ramón Grosfoguel, Nelson Maldonado-Torres and José David Saldívar. Boulder: Paradigm Publishers, 2005, pp. 75-88.

Serra, Ana. "Conspicuous Absences: Representations of Race in Post-1959 Cuban Film," Confluencia, vol 20, no. 1, 2004, pp. 134-146.

Vasconcelos, José. La raza cósmica/The Cosmic Race: A Bilingual Edition. Translated and annotated by Didier T. Jaén. Baltimore: The Johns Hopkins University Press, 1997.

Yaszek, Lisa. “An Afrofuturist Reading of Ralph Ellison's Invisible Man," Rethinking History: The Journal of Theory and Practice, vol. 9, no. 2 (3), pp. 297-313.

---. "Afrofuturism, Science Fiction, and the History of the Future," Socialism and Democracy, vol. 42, no. 20 (3), 2006, pp. 41-60. 